\title{
BUPATI PEREMPUAN PERTAMA DI LAMPUNG DAN KEGAGALAN CALON PETAHANA PADA PILKADA DI LAMPUNG TIMUR TAHUN 2015
}

\author{
Oleh: Hertanto* $\&$ Handi Mulyaningsih ${ }^{\bullet}$
}

\begin{abstract}
In Indonesia, women were elected as governors, regents, mayors and deputy regional head is still small. The same phenomenon occurred in Lampung during the election period of 2005-2014, not a single female candidate was elected as regional head and deputy regional head. New on the elections in 2015 elected two women as East Lampung Regent (Chusnunia Chalim) and Vice Regent of Pesisir Barat (Erlina). The purpose of this study to determine the factors Chusnunia Chalim victory (and a couple Zaiful Bokhari) in local elections in East Lampung district in 2015. Theoretical framework used to explain the modalities of political contestation of the election, assuming that the candidate that wins must have the capital that includes political capital, social capital, and economic capital. This study used a descriptive approach qualitative research informants the winning team mate Chusnunia Chalim and Zaiful Bokhari, Commissioner of the East Lampung Regency, local community leaders, and some leaders of political parties bearers and supporters of the candidate. Discussion of the results showed that women's involvement in political elections and local governments began to seem real. Chusnunia because social capital is consolidated with the political capital of the bearers of political parties (PKB and PD) and the PDI$P$ supporters of political parties. This victory more dominant factor in social capital and strengthened by the political capital that appears at times the last round of the campaign. Social capital is obtained from the ethnic affiliation of voters with candidates and religious culture of the majority of the population of East Lampung. Meanwhile, the advantage of the element of political capital gained from the failure of incumbent candidates in the voting stage. So that prospective incumbent and its main bearers of political parties, PDI-P, shift support to Chusnunia.
\end{abstract}

Keywords: Local political contestation; Social Capital, Politics, Economics; Regent Women

\section{PENDAHULUAN}

\footnotetext{
${ }^{*}$ Dosen pada Jurusan Ilmu Pemerintahan dan Ketua Program Magister Ilmu Pemerintahan Fakultas Ilmu Sosial dan Ilmu Politik Universitas Lampung.

-Dosen pada Jurusan Sosiologi Fakultas Ilmu Sosial dan Ilmu Politik Universitas Lampung. Saat ini sebagai Komisioner KPU Provinsi Lampung periode 2014-2019.
} 
Partisipasi perempuan dalam proses politik pemilihan kepala daerah (pilkada) masih rendah. Jumlah dan keterpilihan perempuan belum banyak dalam pilkada. Di Indonesia, perempuan yang terpilih sebagai gubernur, bupati, dan wakil kepala daerah masih sedikit. Berdasarkan data komisi pemilihan umum (KPU) di tingkat daerah, hanya 46 orang perempuan pemenang Pilkada Serentak di 264 daerah (KPU RI, 2015). Dalam Pilkada 2015 ini, hanya 45 daerah yang melahirkan perempuan pemimpin, yakni di 39 kabupaten dan 6 kota. Ada 24 orang perempuan yang terpilih sebagai kepala daerah, dan 22 orang perempuan yang terpilih sebagai wakil kepala daerah. Angka ini terlampau kecil,hanya 17 persen,bila dibandingkan dengan banyak daerah yang dimenangkan laki-laki.

Jika dibandingkan dengan jumlah kepala dan wakil kepala daerah yang memenangkan pilkada, ada 46 perempuan dari 528 orang atau 8,7 persen yang memenangkan Pilkada di 264 daerah. Keterpilihan perempuan calon kepala daerah tak mencapai separuh dari jumlah pencalonan. Berdasarkan data tersebut, hanya 46 perempuan kepala daerah yang terpilih dari 124 perempuan yang mencalonkan diri sebagai kepala daerah. Angka tersebut menunjukkan keterpilihan perempuan hanya mencapai 37,1 persen, jadi tidak sampai separuhnya. Mereka menang dengan perolehan suara rata-rata 57,44 persen. Sementara dalam keterpilihan wakil kepala daerah, 33,33 persen perempuan terpilih sebagai wakil kepala daerah (22 dari 66 perempuan yang mencalonkan diri). Rata-rata kemenangannya berada di kisaran 44,57 persen (Perludem, 2015). Perempuan kepala daerah terpilih didominasi oleh petahana dan kader partai, sekitar 12 dari 24 perempuan (50 persen). Jumlah ini paling banyak dibanding dengan latar belakang lain, seperti perempuan kepala daerah terpilih yang berlatar belakang mantan anggota DPR/DPRD/DPD. Sementara perempuan wakil kepala daerah didominasi oleh mantan anggota DPR/DPD/DPRD. Sebanyak 9 dari 22 (40,91 persen) perempuan berlatar 
belakang mantan anggota DPR/DPD/DPRD. Di posisi kedua, sebanyak 6 dari 22 (36,36 persen) perempuan adalah kader partai. Sementara perempuan yang mempunyai hubungan kekerabatan dengan elit berjumlah 8 dari $22(27,27$ persen).

Namun, jumlah perempuan yang terpilih menjadi kepala daerah dan wakil kepala daerah pada Pilkada 2017 menurun jika dibandingkan dengan Pilkada 2015. Pada pilkada yang digelar di 101 daerah ini, calon perempuan yang jadi pemenang berdasarkan hasil real counthanya 13 orang (Titi Anggraini, 2017). Total calon perempuan yang ikut berkompetisi sebanyak 40 orang. Pada pilkada sebelumnya yang diikuti 269 daerah, jumlah calon perempuan yang berkompetisi sebanyak 123 orang, dan yang berhasil terpilih 35 orang. Meski dari sisi persentase keterpilihan terjadi kenaikan, dari sisi jumlah baik yang mencalonkan maupun yang terpilih terjadi penurunan. Di antara calon perempuan yang menang tersebut yakni Neneng Hasanah (calon bupati Bekasi),
Idza Priyanti (calon bupati Brebes), Karolin Margret Natasa (calon bupati Landak), Dewanti Rumpoko (calon bupati Batu), Masnah (calon bupati Muaro Jambi), dan Winarti (calon bupati Tulangbawang, Lampung).

Menurut Titi Anggraini (2017), salah satu penyebab calon perempuan sedikit yang terpilih adalah mekanisme pilkada yang hanya mengenal satu putaran (kecuali DKI Jakarta). Kondisi ini membuat partai politik berpikir pragmatis dan hanya berorientasi bagaimana memenangkan pilkada. Akibatnya, partai hanya melirik caloncalon yang mempunyai elektabilitas, popularitas, dan kemampuan finansial yang mumpuni untuk dimajukan sebagai calon. Akhirnya perempuan menjadi terpinggirkan ketika parameter utama dalam pencalonan adalah elektabilitas, popularitas, dan modal finansial tersebut. Menurut Sigit Pamungkas (2011), ketika sudah masuk pada tahap pemilihan, faktor keterpilihan kandidat perempuan sangat tergantung pada keterampilan dan kemampuannya mengakumulasi dukungan. Faktor lain yang juga 
mungkin berpengaruh pada ketidakterpilihan calon perempuan adalah budaya politik setempat yang kadang tidak menempatkan perempuan sebagai alternatif pemimpin.

Fenomena yang sama terjadi di Lampung selama periode pilkada tahun 2005-2014, tidak ada satu pun calon perempuan terpilih sebagai kepala daerah dan wakil kepala daerah; baik sebagai gubernur, wakil gubernur, bupati, wakil bupati, walikota, maupun wakil walikota. Baru pada pilkada tahun 2015 terpilih dua perempuan sebagai Bupati Lampung Timur (Chusnunia Chalim) dan Wakil Bupati Pesisir Barat (Erlina). Dengan demikian, mereka adalah kepala dan wakil kepala daerah perempuan pertama di Lampung yang terpilih melalui pilkada. Oleh karena itu, fokus kajian ini adalah untuk mengetahui faktor-faktor kemenangan Chusnunia Chalim (dan pasangan Zaiful Bokhari) pada Pemilihan Kepala Daerah di Kabupaten Lampung Timur Tahun 2015.

Para kandidat yang mengikuti kontestasi di dalam pilkada harus memiliki modal yang meliputi modal politik, modal sosial, dan modal ekonomi. Asumsinya, pasangan calon kepala daerah yang memiliki peluang besar terpilih manakala memiliki akumulasi lebih dari satu modal. Semakin besar pasangan calon yang mampu mengakumulasi tiga modal: politik, sosial, dan ekonomi; semakin besar berpeluang terpilih sebagai kepala daerah. Sementara pada sisi masyarakat,perilaku memilih seseorang dipengaruhi oleh aspek-aspek rasionalitas dan emosionalitas, seperti sosial ekonomi, afiliasi etnis, tradisi keluarga, keanggotaan terhadap organisasi, usia, jenis kelamin, pekerjaan, tempat tinggal, dan lain-lain (Bismar, 2011).

\section{TINJAUAN TEORITIK}

\section{Modalitas dalam Kontestasi Politik}

Pemilihan kepala daerah (pilkada) adalah arena politik yang dinamis dimana terdapat pertarunganpertarungan guna memperebutkan posisi-posisi dan jabatan-jabatan politik. Pertarungan tersebut sangat berkaitan erat dengan kepemilikan 
modal (capital). Pilkada merupakan salah satu proses demokrasi secara prosedural untuk memilih pemimpin daerah dimana kemenangan ditentukan oleh perolehan suara terbanyak. Didalam demokrasi lokal ini, semua warga yang memenuhi syarat undangundang memiliki kesempatan yang samauntuk mencalonkan diri. Pasangancalon (paslon) kepala daerahmencari dukungan partai politik atau masyarakat, menawarkan program-program politik, dan ikut berkompetisi dalam pilkada apabila telah ditetapkan sebagai calon oleh KPU setempat.

Namun dalam kenyataan, kesempatan itu sebenarnya tidak sama antara satu warga dengan yang lain karena kemampuan modal yang dimiliki setiap orang dalam kontestasi pilkada berbeda-beda. Di dalam proses pilkada sebagai arena kontestasi politik dengan memilih orang dan kompetisi antarkandidat, kandidat yang kemungkinan memenangkan pilkada manakala memiliki modalitas terstruktur. Modal utama yang harus dimiliki para kandidat yang hendak mengikuti kontestasi didalam pilkada, yaitu modal politik, modal sosial, dan modal ekonomi (Marijan, 2010: 184). Pasangan calon kepala daerah itu memiliki peluang besar terpilih manakala memiliki akumulasi lebih dari satu modal, semakin besar pasangan calon yang mampu mengakumulasi tiga modal itu, semakin berpeluang terpilih sebagai kepala daerah. Peluang terpilihnya pasangan kandidat merupakan bagian dari proses yang kompleks, maka tidak bisa dikatakan sebagai hasil hanya dari salah satu faktor saja atau modalitas tertentu.

\section{Modal Politik (Political Capital)}

Modal politik berarti adanya dukungan politik, baik dari rakyat maupun dari kekuatan-kekuatan politik yang dipandang sebagai representasi dari rakyat (Marijan, 2010: 184). . modal politik ini memiliki makna yang sangat penting karena pilkada langsung menggunakan mekanisme 'party system' (Berman dalam Marijan, 2010). Kandidat dalam pilkada memerlukan dukungan politik yang diusung dari partai politik (parpol) atau koalisi 
parpol. Kandidat akan berusaha sebanyak mungkin menggalang koalisi partai politik yang mendapatkan kursi di DPRD dan suara hasil pemilu legislatif. Fungsi partai politik dalam pilkada sebagai sarana untuk memobilisasi dukungan bagi kandidat yang ingin memenangkan pilkada harus sebanyak mungkin memanfaatkan jaringan organisasi-organisasi politik untuk memperoleh dukungan politik, di samping karena pengaruh figur kandidat terhadap pemilih.

Casey sebagaimana dikutip Sudirman Nasir (2009) mendefinisikan modal politik sebagai pendayagunaan keseluruhan jenis modal yang dimiliki seorang pelaku politik atau sebuah lembaga politik untuk menghasilkan tindakan politik yang menguntungkan dan memperkuat posisi pelaku politik atau lembaga politik bersangkutan. Casey lebih lanjut memerinci adanya empat pasar politik yang berpengaruh pada besaran modal politik yang dimiliki oleh seorang pelaku politik atau sebuah lembaga politik. Pasar politik pertama adalah pemilu karena pemilu adalah instumen dasar untuk pemilihan pemimpin dalam sistem demokrasi. Pasar politik kedua adalah perumusan dan pelaksanaan kebijakankebijakan publik. Pasar politik ketiga adalah dinamika hubungan dan konflik antara pelaku politik dan lembaga politik dalam perumusan dan pelaksanaan kebijakan-kebijakan publik. Pasar politik keempat adalah pendapat atau pandangan umum (public opinion) mengenai pelaku politik atau lembaga politik itu.

Dengan demikian, modal politik adalah berbagai fokus pemberian kekuasaan atau sumber daya untuk merealisasikan hal-hal yang dapat mewujudkan kepentingan meraih kekuasaan. Intinya, modal politik adalah kekuasaan yang dimiliki seseorang, yang kemudian bisa dioperasikan atau berkontribusi terhadap keberhasilan kontestasinya dalam proses politik seperti pemilihan umum.

\section{Modal Sosial (Social Capital)}

Di dalam ilmu politik, konsep modal sosial umumnya dikaitkan dengan relasi antarwarga negara dan 
antara warga negara dengan pemimpinnya dalam membentuk bangunan negara demokrasi (Putnam dalam Marijan, 2010). Modal sosial berkaitan dengan bangunan relasi dan kepercayaan (trust) yang dimiliki pasangan calon dengan masyarakat pemilihnya (Marijan, 2010: 185). Selain dukungan kandidat dari parpol, kandidat juga harus berusaha sebanyak mungkin memperoleh dukungan dari kekuatan-kekuatan nonpolitik seperti organisasi keagamaan, pemuda, profesi dan lainnya (Haryanto, 2005: 72).

Dalam konteks politik lokal banyak terdapat elit-elit yang menduduki jabatan politik dan jabatanjabatan strategis yang mempunyai peran penting dan pengaruh terhadap kelompok dan masyarakat di daerah tersebut. Menurut Nurhasim, dkk (2003), elit politik lokal adalah mereka yang memiliki jabatan politik tinggi di tingkat lokal yang membuat dan menjalankan kebijakan politik. Elit politiknya seperti gubernur, bupati, walikota, ketua DPRD, anggota DPRD, maupun pemimpin-pemimpin partai yang ada di tingkat daerah. Sedangkan, elit nonpolitik lokal adalah seseorang yang menduduki jabatan-jabatan strategis dan mempunyai pengaruh untuk memerintah orang lain dalam lingkup masyarakat. Elit nonpolitik ini seperti elit keagamaan, elit organisasi masyarakat, kepemudaan, profesi dan lain sebagainya (Nurhasim, dkk, 2003: 8).

Pengaruh ketokohan dan popularitas, latar belakang pendidikan dan pekerjaan kandidat serta jaringan yang terhadap elit-elit sosial tersebut akanmenentukan pemenangan pilkada, karena untuk membangun relasi dan kepercayaan dari masyarakat kandidat harus memiliki pengaruh tersebut. Sejumlah ahli menyampaikan pandangan berbeda tentang modal sosial tetapi memiliki korelasi seperti diolah Mefi Hermawati (2002). Menurut Robert Putnam (2000), modal sosial adalah suatu mutual trust antara anggota masyarakat dan masyarakat terhadap pemimpinnya. Modal sosial didefinisikan sebagai institusi sosial yang melibatkan jaringan (networks), norma-norma (norms), dan kepercayaan sosial (social trust) yang 
mendorong kepada sebuah kolaborasi sosial (koordinasi dan kooperasi) untuk kepentingan bersama. Pendapat ini mengandung pengertian diperlukan ikatan/jaringan sosial yang ada dalam masyarakat, dan norma yang mendorong produktivitas. Putnam juga melonggarkan makna assosiasi horisontal, tidak hanya yang memberi desireable outcome (hasil pendapatan yang diharapkan) melainkan juga undesirable outcome (hasil tambahan).

Pierre Bourdieu dalam Haryatmoko (2003), mendefinisikan modal sosial sebagai "sumber daya aktual dan potensial yang dimiliki seseorang berasal dari jaringan sosial yang terlembagakan serta berlangsung terus menerus dalam bentuk pengakuan dan perkenalan timbal balik (atau dengan kata lain: keanggotaan dalam kelompok sosial) yang memberikan kepada anggotanya berbagai bentuk dukungan kolektif. Pendapatnya menegaskan tentang modal sosial mengacu pada keuntungan dan kesempatan yang didapatkan seseorang di dalam masyarakat melalui keanggotaannya dalam entitas sosial tertentu (paguyuban, kelompok arisan, asosiasi tertentu).

James Coleman

(1988)

mendefinisikan modal sosial sebagai suatu yang memiliki dua ciri, yaitu merupakan aspek dari struktur sosial serta memfasilitasi tindakan individu dalam struktur sosial tersebut. Dalam pengertian ini, bentuk-bentuk modal sosial berupa kewajiban dan harapan, potensi informasi, norma dan sanksi yang efektif, hubungan otoritas, serta organisasi sosial yang bisa digunakan secara tepat dan melahirkan kontrak sosial. Modal sosial bagi Fukuyama (2002) adalah kapabilitas yang muncul dari kepercayaan umum di dalam sebuah masyarakat atau dibagianbagian tertentu darinya.

\section{Modal Ekonomi (Economical Capital)}

Modal ekonomi berangkat dari pemahaman terhadap benda yang memiliki nilai ekonomis yang disimbolkan dengan uang/mata uang. Dalam perspektif ekonomi, modal bisa pula berupa investasi yang diberikan seseorang pada pihak lain, kemudian 
dipertukarkan dengan keuntungan berupa barang atau uang/jasa politik. Modal ekonomi memiliki makna penting sebagai "penggerak" dan "pelumas" mesin politik yang dipakai (Marijan, 2010: 187). Di saat musim kampanye dibutuhkan uang yang besar untuk membiayai berbagai kebutuhan seperti mencetak poster, spanduk, membayar iklan, dan berbagai kebutuhan yang lainnya. Bahkan modal ekonomi dapat menjadi prasyarat utama ketika calon itu bukan berasal dari partai yang dicalonkannya.

Modal politik dan ekonomi saling berkaitan dalam iklim politik yang menekankan kepada interaksi spontan (jarak waktu komunikasi yang pendek) antara pemilih dan calon politik (Sahdan dan Haboddin, 2015). Waktu yang pendek dalam sosialisasi diri, mendorong calon menggunakan modal ekonomi sebagai jalur pintas. Kondisi ini banyak terjadi di negaranegara berkembang yang masih dalam proses transisi menuju pemilu rasional dan penciptaan pemilih rasional. Karena itu, kandidat juga memerlukan dukungan ekonomi yang berasal dari para pelakuekonomi dan pengusaha untuk pemenangan pilkada. Dana ini bisa berasal dari sumbangan pasangan kandidat sendiri dan sumbangan dari para simpatisan (donatur) baik secara perseorangan maupun korporasi. Dana politik juga bisa diartikan sebagai wujud konkrit dari partisipasi dan dukungan masyarakat terhadap pasangan kandidat kepala daerah.

Menurut Sahdan dan Haboddin (2015), proses politik pilkada membutuhkan biaya dan ongkos yang sangat mahal. Mahalnya ongkos pilkada disebabkan oleh 3 (tiga) faktor, yaitu: pertama, pasangan calon kepala daerah yang akan bertarung diharuskan membeli partai politik sebagai kendaraan politik. Partai politik yang akan dijadikan kendaraan dalam pemilihan kepala daerah mengharuskan pasangan calon untuk menyetor dana sumbangan hingga miliaran rupiah (Marijan, 2010). Kedua, model kampanye politik yang dilakukan oleh pasangan calon membutuhkan banyak biaya. Misalnya, buat poster, pemasangan iklan di media massa baik cetak maupun elektronika. Ketiga, 
membeli pemilih (vote buying) untuk membujuk pemilih dengan menggunakan praktek politik uang. Model pemberian uang kepada pemilih biasanya dilakukan hampir pada setiap proses pentahapan pilkada (Muhammad Amin, 2014).

\section{METODE KAJIAN}

Kajian ini menggunakan menggunakan pendekatan deskriptif kualitatif untuk menjelaskan, menggambarkan dan menafsirkan hasil analisis datauntukmenjawab permasalahan yang dikaji (Bogdan, 1975). Kajian difokuskan untuk mendapatkan gambaran dan keterangan-keterangan secara jelas dan faktual tentang kemenangan Chusnunia Chalim (dan pasangan Zaiful Bokhari) pada Pemilihan Kepala Daerah di Kabupaten Lampung Timur Tahun 2015.

Tempat atau lokasi yang dilakukan dalam penelitian ini adalah Kabupaten Lampung Timur antara September sampai November 2016. Informan penelitian ditujukan kepada tim pemenangan dan petugas penghubung pasangan Chusnunia Chalim dan Zaiful Bokhari, Komisi Pemilihan Umum (KPU) Kabupaten Lampung Timur, petugas pemilihan dan pengawas kecamatan, tokoh masyarakat setempat, dan beberapa pimpinan parpol pengusung/pendukung pasangan calon. Pengumpulan data utama lebih banyak menggunakan wawancara mendalam dengan para informan tersebut. Sumber data lain diperoleh dari pengamatan dan dokumentasi resmi dari KPU Kabupaten Lampung Timur dan KPU Provinsi Lampung.

\section{PEMBAHASAN KAJIAN}

\section{A. Pilkada Lampung Timur 2015}

Pilkada serentak tahun 2015 di Lampung terselenggara pada lima kabupaten dan dua kota yang diikuti oleh 27 pasangan calon, tiga di antaranya calon perempuan (Chusnunia Chalim, Erlina, dan Megasari). Dua di antaranya terpilih sebagai bupati (Chusnunia di Lampung Timur) dan wakil bupati (Erlina di Pesisir Barat). 
Pemilihan kepala daerah dan wakil kepala daerah di Kabupaten Lampung Timur diselenggarakan pada tanggal 9 Desember 2015. Pilkada ini diikuti oleh dua pasangan calon, yaitu nomor urut satu Yusran Amirullah berpasangan dengan Sudarsono dan Chusnunia Chalim berpasangan dengan Zaiful Buchari. Pasangan Yusran Amirullah dan Sudarsono diusung/didukung oleh Partai Nasional Demokrat (NASDEM), Partai Golkar (PG), Partai Gerakan Indonesia Raya (GERINDRA), Partai Persatuan Pembangunan (PPP), dan Partai Hati Nurani Rakyat (HANURA). Sedangkan pasangan Chusnunia Chalim dan Zaiful Buchari diusung/didukung oleh Partai Kebangkitang Bangsa (PKB) dan Partai Demokrat (PD).

Berdasarkan hasil penetapan KPU Kabupaten Lampung Timur, pasangan nomor urut satuYusran Amirullah dan Sudarsono mendapatkan 232. 455 suara $(46,83$ persen $)$. Sedangkan pasangan nomor urut dua Chusnunia Chalim dan Zaiful Buchari mendapatkan 263. 926 suara $(53,17$ persen). Rapat pleno perhitungan suara yang dilakukan Komisi Pemilihan Umum Daerah (KPUD) Lampung Timur hari Kamis Tanggal 17 Desember 2015 menetapkan pasangan Chusnunia Chalim-Zhaiful Bokhari sebagai pemenang pemilihan bupati tahun 2015.

\section{B. Faktor-Faktor Kemenangan}

\section{Profil Bupati Lampung Timur}

Chusnunia Chalim adalah anggota DPR RI dari fraksi Partai Kebangkitan Bangsa (PKB) selama hampir dua periode dari daerah pemilihan (dapil) Lampung II, 20092014 dan 2014-2019. Chusnunia merupakan alumnus Fakultas Syariah, Universitas Islam Negeri (IAIN) Walisongo, Semarang dan magister Ilmu Politik, Universitas Nasional, Jakarta. Perempuan kelahiran 12 Juli 1982 ini berusia 33 tahun pada saat dilantik sebagai bupati. Bagi warga Lampung pada umumnya, namanya mungkin relatif kurang dikenal,tapi sangat dikenal oleh warga masyarakat Lampung Timur. Chusnunia pernah menjabat Wakil Sekretaris Jenderal 
Dewan Pimpinan Pusat (DPP) PKB 2009-2014. Ia juga pernah menjadi Staf Khusus Menteri Tenaga Kerja Erman Soeparno dan Bendahara Umum PKB pada 2007-2008 (Dimas, 2017).

Sedangkan wakil Bupati Lampung Timur, Zaiful Bokhari, seorang pengusaha yang menjadi Ketua DPC Partai Demokrat Lampung Timur periode 2008-2016 dan menjadi anggota DPRD Kabupaten Lampung Timur periode 2014-2019 (KPU Lampung Timur, 2015).

\section{Modal Politik}

Modal politik Chusnunia dan pasangannya tidak besar karena hanya diusung/didukung oleh dua parpol kategori menengah (PKB dan PD), dibandingkan dengan lawannya yang diusung/didukung oleh lima parpol yang salah satu satunya tergolong besar (Partai Golkar). PKB di DPRD Lampung Timur berjumlah 7 kursidan Partai Demokrat hanya 5 kursi. Jadi bila direpresentasikan pada jumlah pemilih dua partai tersebut tidak signifikan bagi kemenangan Chusnunia dan pasangannya. Artinya modal politik bukan menjadi penentu kemenangan mereka.

Hanya kedua pasangan pemenang pilkada tersebut diuntungkan oleh gagalnya calon petahana untuk ikut berlaga pada tahapan pencoblosan. Semula, ada tiga pasangan calon pilkada Lampung Timur tahun 2015 yang ditetapkan KPU setempat sebagai calon kepala daerah dan wakilnya. Namun, pada saat menjelang pelaksaan kampanye, calon wakil bupati pasangan Erwin Arifin (bupati petahana) Erwin Arifin (bupati petahana) nomor urut 3 meninggal dunia, yaitu Prio Budi Utomo. Berdasarkan keputusan KPU Kabupaten Lampung Timur atas dasar Peraturan KPU nomor 9 Tahun 2015 tentang pencalonan, maka KPU Kabupaten Lampung Timur memutuskan untuk menggugurkan pasangan Erwin Arifin dan Prio Budi Utomo. Sehingga KPU Lampung Timur pun menggugurkan pencalonan Erwin Arifin, tanpa dapat menggantikan calon wakilnya yang wafat tersebut. Calon petahana Erwin 
Arifin diusung PDI-P dan koalisi lainnya PKS dan PAN. Pada akhirnya Erwin dan PDI-P mengalihkan dukungan kepada Chusnunia dan pasangannya pada saat-saat terakhir menjelang hari pencoblosan. PDI-P adalah parpol pemenang pemilu legislatif tahun 2014 di Lampung Timur dengan perolehan sembilan (9) kursi di DPRD setempat. Sedangkan PKS dan PKB menempati rangking kedua dengan masing-masing memperoleh tujuh (7) kursi di DPRD.

Pada awalnya persaingan sengit antarcalon di pilkada Lampung Timur tahun 2015 adalah antara calon petahana Erwin Arifin dan penantang kuatnya sekaligus rival 'abadinya' Yusran Amirullah (Partai Nasdem). Arus opini umum hanya mengarah pada dua pasangan calon tersebut yang kemunginan akan memenangkan pilkada Lampung Timur daripada kepada Chusnunia dan pasangannya. Pasangan terakhir ini hanya dianggap sebagai pelengkap dalam persaingan dan kompetisi antarkandidat pada pilkada Lampung Timur. Tetapi meninggalnya pasangan Erwin,yang menyebabkan gagalnya calon petahana ini untuk mengikuti tahapan berikutnya, mengubah peta dukungan politik. Kubu pasangan Yusran Amirullah dan Sudarsono merasa paling optimis akan memenangkan pilkada setelah pesaing utamanya digugurkan oleh KPU Lampung Timur. Apalagi akhirnya pasangan YusronSudarsono ini mendapatkan dukungan dari Partai Keadilan Sejahtera (PKS) dan Partai Amanat Nasional (PAN) setelah gagal mendukung calon petahana.

Secara politik lokal, Chusnunia merupakan pendatang baru dibandingkan lawannya yang sudah dua kali terlibat sebagai calon pada pilkada Lampung Timur. Lain dari itu, persepsi sebagian masyarakat Kabupaten Lampung Timur menganggap bahwa kapasitas seorang perempuan belum mampu memimpin suatu wilayah.

\section{Modal Sosial}

Terpilihnya Pasangan

Chusnunia-Zaiful menjadi Bupati dan Wakil Bupati Kabupaten Lampung 
Timur berbekal modal sosial yang baik. Dalam bentuk modal sosial yang dimiliki Pasangan Chusnunia-Zaiful, Masyarakat Kabupaten Lampung Timur mengenal sosok Chusnunia Chalim sebagai aktivis politik yang ramah dan memiliki sifat kesederhanaan serta memiliki tingkat sosialisasi yang tinggi terhadap masyarakatnya. Chusnunia Chalim merupakan putri pertama KH. Abdul Chalim (Almarhum) yang berlatar belakang dari kalangan pesantren Nahdlatul Ulama (NU) dan dihormati di kalangan pesantren serta masyarakat setempat.

Pasangan Chusnunia-Zaiful memanfaatkan jumlah massa dari kalangan organisasi kemasyarakatan (ormas) keagamaan NU ini, antara lain kelompok ibu-ibu pengajian (Fatayat), dan Gerakan Pemuda (GP) Ansor, dan organisasi sayap lainnya. Sebagian besar penduduk Kabupaten Lampung Timur bergerak di sektor pertanian yang menganut tradisi NU. Sebagian besar dari mereka adalah etnis keturunan Jawa sama seperti Chusnunia. Kemenangan calon lebih dominan didukung oleh jaringan keluarga, kekerabatan, keorganisasian sosial keagamaan, dan kesamaan etnis antara calon dengan mayoritas pemilih di Lampung Timur.

Berdasarkan pada pembahasan tersebut dapat disimpulkan bahwa modal sosial merupakan kekuatan paling dominan yang dimiliki oleh Pasangan Chusnunia-Zaiful dibandingkan dari lawannya yaitu Pasangan Yusron-Sudarsono karena masyarakat di Kabupaten Lampung Timur sebenarnya sudah mengenal lebih lama dibandingkan pasangan Yusron-Sudarsono.

\section{Modal Ekonomi}

Modal ekonomi yang dimiliki oleh Pasangan Chusnunia-Zaiful sebagai dana kampanye tidak besar dibandingkan lawannya yaitu pasangan Yusron-Amirullah, pasangan terakhir ini lebih siap untuk melakukan kampanye mencetak brosur, poster, juga untuk bayar partai politik yang akan dijadikan kendaraan politik, dan lainnya. 
Berdasarkan data dari KPU Kabupaten Lampung Timur tentang Laporan Penerimaan dan Pengeluaran Dana Kampanye (LPPDK) pasangan Yusron-Sudarsono periode 25 Agustus 2015 sampaidengan 5 Desember 2015
Model LPPDK-1, pasangan YusronSudarsono memiliki total modal sebesar Rp 1. 280. 342. 206 yang diantaranya sebesar Rp 550. 000. 000 bersumber dari dana sumbangan simpatisan.

Tabel 1. Dana Kampanye Pasangan Calon Bupati dan Wakil Bupati Kabupaten Lampung Timur Tahun 2015

\begin{tabular}{|r|c|r|c|}
\hline No. & $\begin{array}{r}\text { Nama Pasangan } \\
\text { Calon }\end{array}$ & $\begin{array}{r}\text { Total Dana } \\
\text { Kampanye }\end{array}$ & $\begin{array}{r}\text { Total Dana yang } \\
\text { digunakan/ } \\
\text { dikeluarkan }\end{array}$ \\
\hline 1. & Yusron-Sudarsono & Rp 1.280.342. & Rp 949. 500. 441,- \\
\hline 2. & Chusnunia-Zaiful & Rp 650.000.000,- & Rp 274.500.000,- \\
\hline
\end{tabular}

Sumber: Dimas, 2017: 87.

Pasangan Yusron-Sudarsono memiliki modal lebih besar dibandingkan dengan pasangan Chusnunia-Zaiful, hal ini yang membuat pasangan Chusnunia-Zaiful memiliki kendala dalam bentuk ekonomi. Berdasarkan penjelasan diatas, maka penulis dapat menyimpulkan bahwa kampanye dapat gagal mungkin hanya karena anggaran untuk membiayai program tersebut tidak memadai sehingga pelaku kampanye tak bisa berbuat total.

Pasangan Chusnunia-Zaiful mempunyai modal sebesar Rp 605.
000. 000 diantaranya bersumber dari dana sumbangan simpatisan sebesar Rp 110. 000. 000. Berdasarkan data dari KPU Kabupaten Lampung Timur 2015 tentang Laporan Dana Kampanye Pasangan Chusnunia Chalim dan Zaiful Bokhari periode 27 Agustus sampai dengan 16 Oktober 2015 Model LPSDK(Laporan Penerimaan Sumbangan Dana Kampanye), pasangan Chusnunia-Zaiful mendapatkan dana sumbangan dari para simpatisan (donatur) sebanyak empat orang dari penyumbang data perseorangan. 
Tabel 2. Daftar Penerimaan Sumbangan Dana Kampanye

Pasangan Calon Chusnunia-Zaiful

\begin{tabular}{|r|l|c|c|}
\hline No. & Identitas Penyumbang & $\begin{array}{c}\text { Jumlah } \\
\text { Sumbangan }\end{array}$ & $\begin{array}{c}\text { Asal Perolehan } \\
\text { Dana }\end{array}$ \\
\hline 1 & Anggota DPRD Provinsi Lampung & Rp 30.000.000 & Penghasilan Pribadi \\
\hline 2 & Anggota DPRD Lampung Timur & Rp 15.000.000 & Penghasilan Pribadi \\
\hline 3 & Wiraswasta & Rp 50.000.000 & Uang Pribadi \\
\hline 4 & Anggota DPRD Lampung Timur & Rp 15.000.000 & Penghasilan Pribadi \\
\hline
\end{tabular}

Sumber: KPU Kabupaten Lampung Timur Tahun 2015 (dalam Dimas, 2017)

Sebagian besar modal ekonomi pasangan calon Chusnunia-Zaiful digunakan pada saat melaksanakan kampanye. Ongkos politik yang dikeluarkan relatif tidak terlalu besar, karena pasangan calon merupakan kader internal masing-masing parpol pengusungnya. Sehingga tidak uang ada sewa "kendaraan dan mahar" politik kepada parpol pengusung. Dengan demikian, modal ekonomi yang dimiliki pasangan tidak cukup menunjang bagi kemenangan pilkada, dibandingkan dengan kepemilikan modal ekonomi dari pasangan calon lawannya.
Berdasarkan fakta-fakta di atas, faktor kemenangan Chusnunia lebih dominan pada modal sosial dan ditambah modal politik yang muncul pada saat-saat putaran terakhir masa kampanye. Modal sosial diperoleh dari afiliasi etnis pemilih dengan calon dan kultur keagamaan dari mayoritas penduduk Lampung Timur. Sedangkan, keuntungan dari segi modal politik diperoleh dari gagalnya petahana dalam tahapan pemberian suara. Sehingga calon petahana dan parpol pengusung utamanya, PDI-P, mengalihkan dukungan kepada Chusnunia. 
Dari segi gender secara umum, Chusnunia memiliki dukungan yang sangat kuat dari kalangan pemilih perempuan. Faktor gender ini yang pada awal-awal tahap pilkada dianggap akan menjadi kendala terbesar bagi Chusnunia ternyata tidak signifikan.

Sementara menurut peniliti Perludem, Maharddhika (2015),menilai perempuan yang berlatar belakang kader partai, seperti Chusnunia, cukup signifikan angka keterpilihannya. Ada 12 perempuan terpilih dari 19 perempuan $(63,16$ persen $)$ berlatar belakang kader partai yang mencalonkan diri sebagai kepala daerah pada pilkada 2015. Ini menunjukkan mesin partai bekerja baik di daerah dimana perempuan kader partai tersebut mencalonkan. Sehingga parpol dituntut untuk tidak lagi mencalonkan perempuan dengan hanya semata-mata mempertimbangkan elektabilitas tinggi tetapi mulai mencalonkan perempuan yang berkualitas. Partai memiliki pekerjaan rumah untuk mempertemukan signifikansi kehadiran perempuan dengan makin membaiknya integritas dan kualitas. Kualitas perempuan bisa ditingkatkan dengan upaya mendorong perempuan untuk hadir dalam struktur pengurus harian serta terlibat dalam setiap perumusan kebijakan dan pengambilan keputusan internal partai.

\section{KESIMPULAN}

Berdasarkan pembahasan dapat disimpulkan bahwa pada pilkada 2015 di Kabupaten Lampung Timur menunjukkan bahwa keterlibatan perempuan dalam politik dan pemerintahan sudah tampak nyata. Kemenangan calon lebih dominan karena modal sosial yang dikonsolidasikan dengan modal politik dari parpol pengusung (PKB dan PD) dan parpol pendukung PDI-P. Figur calon bupati sebagai sosok yang berlatar belakang dari kalangan santri dan merupakan keturunan dari kyai besar salah satu pendiri Nahdlatul Ulama di Lampung Timur, merupakan modal sosial yang menjadi kekuatan terbesar dari Chununia Chalim untuk menarik simpatik di kalangan masyarakat Kabupaten Lampung Timur. Kekuatan figur ini 
memanfaatkan dukungan dari organisasi masyarakat (ormas) di bidang keagaaman yaitu Nahdlatul Ulama (NU), kelomppok ibu-ibu pengajian (Fatayat), dan Gerakan Pemuda Ansor.

\section{DAFTAR PUSTAKA}

Bismar Arianto. 2011. "Analisis Penyebab Masyarakat Tidak Memilih dalam Pemilu", Jurnal Ilmu Politik dan Ilmu Pemerintahan, Vol. 1, No. 1, Hlm. 1-60.

Bogdan, R. and Taylor, S. J. 1975. Introduction to Qualitative Research Methode. New York: John Willey and Sons, 1975.

Coleman, James. (1988). "Social Capital in the Creation of Human Capital". American Journal of Sociology Supplement 94: S95S120.

Dimas Surya Adi Pamungkas. 2017. "Analisis SWOT Terhadap Kemenangan Pasangan Chusnunia Chalim Dan Zaiful
Bokhari Pada Pemilihan Kepala Daerah Kabupaten Lampung Timur Tahun 2015". Skripsi. Bandar Lampung: Universitas Lampung

Fukuyama, Francis, 2002, Trust, Kebajikan Sosial dan Penciptaan Kemakmuran, (terj. Ruslani), Yogyakarta: Penerbit Qalam.

Haryanto, 2005, Kekuasaan Elit (suatu bahasan pengantar), Yogyakarta: JIP UGM.

Haryatmoko, 2003. "Menyingkap Kepalsuan Budaya Penguasa: Landasan Teoritis Gerakan Sosial Menurut Pierre Bourdieu," dalam Majalah BASIS, Edisi Khusus, November-Desember 2003, hlm. 10-11.

Kacung Marijan. 2010. Sistem Politik Indonesia. Jakarta: Kencana.

Maharddhika, 2015. "Evaluasi Pilkada Serentak 2015", Jurnal 8, http://perludem. org/2016/03/30/jurnal-8evaluasi-pilkada-serentak2015/

Muhammad Amin. 2014. "Golput don Politik Uang dalam Pemilu”. Suara Muhammadiyah, Edisi Nomor 07, Tahun Ke-99, 1-15 April 2014. Hlm. 22-23.

Mefi Hermawanti. 2002. "Penguatan dan Pengembangan Modal 
Sosial Masyarakat Adat", Laporan Need Assesment Pemberdayaan Masyarakat Adat di Nusa Tenggara timur, Yogyakarta: IRE.

Nurhasim, Moch, dkk, 2003, Konflik antar Elit Politik Lokal dalam Pemilihan Kepala Daerah, Jakarta: Pusat Penelitian Politik-LIPI.

Putnam, Robert D. , 2002. Democracies in Flux: The Evolution of Social Capital in Contemporary Society, Oxford University Press.

Sahdan, Gregorius dan Muhtar Haboddin, (Ed), 2009, Evaluasi Kritis Penyelenggaraan Pilkada di Indonesia, Yogyakarta: IPD.

Sigit Pamungkas. 2011. Partai Politik: Teori dan Praktik di Indonesia. Yogyakarta: Institute for Democracy and Welfarism.

Sudirman Nasir. 2009. SBY antara modal politik dan modal simbolik, dalam http://pemilu. liputan6. com/kolom. diakses 18 April 2016 Pukul 16:38 WIB.

Titi Anggraini. 2017. "Keterwakilan Perempuan dalam Pilkada Serentak 2017 Menurun". Tempo. co. tanggal 28 November 2016.

\section{Dokumen}

KPU RI. 2017. http://www. kpu. go. id/index. php/pages/detail/2016/846.

KPU Lampung Timur, 2015. Laporan Penerimaan Sumbangan Dana Kampanye Pasangan Calon Bupati dan Wakil Bupati Kabupaten Lampung Timur Tahun 2015, Model LADK, LPSDK, LPPDK-PARPOL

KPU Lampung Timur, 2015. "Rekapitulasi Hasil Perhitungan Perolehan Suara di Tingkat Kabupaten/ Kota dalam Pemilihan Bupati dan Wakil Bupati Tahun 2015," Model DB- KWK. KPU Kabupaten Lampung Timur Tahun 2016.

Perkumpulan untuk Pemilu dan Demokrasi (Perludem), 2015. "Keterwakilan Perempuan di Pilkada 2015 Hanya 7 Persen". Trbunnews. com. Tanggal 13 September 2015.

Undang-Undang Republik Indonesia Nomor 10 Tahun 2016 Tentang Perubahan Kedua Atas UndangUndang Nomor 1 Tahun 2015 Tentang Penetapan Peraturan Pemerintah Pengganti UndangUndang Nomor 1 Tahun 2014 Tentang Pemilihan Gubernur, Bupati, dan Walikota Menjadi Undang-Undang. 